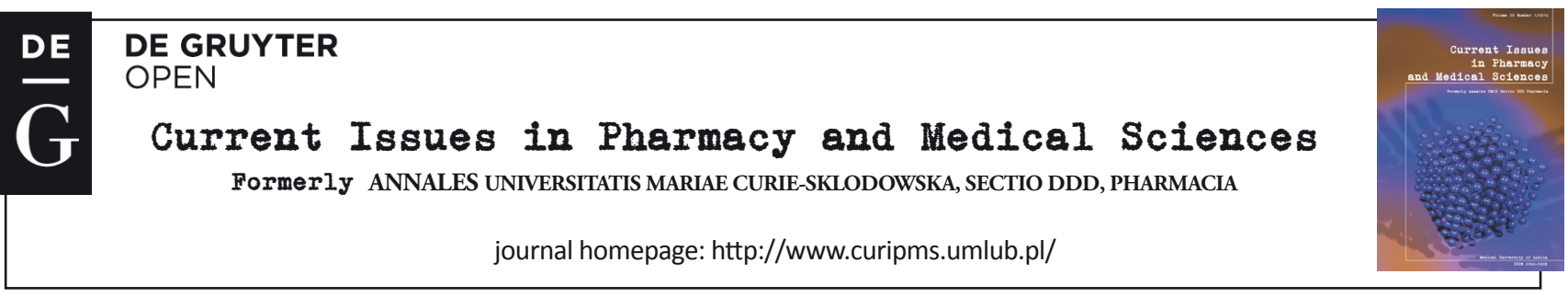

\title{
Bone metabolism and RANKL/RANK/OPG trail in periodontal disease
}

\author{
Lukasz Czupkallo ${ }^{1 *}$, Mansur Rahnama ${ }^{1}$, Dominik Kielbowicz ${ }^{1}$, \\ Michal LobaCZ ${ }^{1}$, Maryla Kozicka-CZupKallo ${ }^{2}$
}

${ }^{1}$ Chair and Department of Oral Surgery, Medical University of Lublin, Poland

2 'DentArtis' Dental Office, Lublin, Poland

\section{ARTICLE INFO}

Received 21 March 2016

Accepted 14 July 2016

\section{Keywords:}

bone metabolism

periodontitis,

RANKL/RANK/OPG,

cytokins.

\begin{abstract}
Periodontal disease is an inflammatory disease of multifactorial etiology. In order for it to appear there must come to an imbalance between the effects of pathogens and host defense mechanisms. As a result of its course the destruction of structures supporting the teeth appears (periodontium, cement, bone), and consequently leads to teeth loosening and loss. In recent years, the participation of RANKL/RANK/OPG in bone remodeling process was highligted.

At the molecular level the bone resorption is regulated through the interaction of the ligand receptor activator of nuclear NF-kappa B (RANKL) and osteoprotegerin (OPG), which is a system of two proteins belonging to the protein tumor necrosis factor (TNF). Recent findings about the RANKL protein and OPG have shed new light on the previously unexplained phenomenon of the basis of bone resorption.

Research has shown that both protein OPG and RANKL can be detected in gingival crevicular fluid, which has become a window of opportunity in the analysis of noninvasive markers of periodontal tissues, confirming elevated levels of RANKL protein in periodontal disease, and decreased levels of OPG protein. Bone resorption is initiated by the binding of the RANKL protein to receptors RANK present on the surface of mature osteoclasts, and their precursors, which leads to the differentiation and activation of osteoclasts. OPG, being RANKL's inhibitor, has, in turn, opposite characteristics to RANKL, resulting in the reduction of osteoclastogenesis process. Despite all this, the exact mechanism of bone resorption has not yet been elucidated.
\end{abstract}

Periodontal disease is an inflammatory disease of multifactorial aetiology. Bacterial infection is crucial here. Such bacterium species as Porphyromonas gingivalis, Aggregatibacter actinomycetemcomitans, Treponema denticola or Fusobacterium nucleatum are among those particularly pathogenic. While gingivitis is completely reversible and does not cause any permanent changes in tissue, periodontitis is a disease that leads to destruction of gingiva, periodontium, bone and cementum, consequently leading to teeth loosening and loss. The entire process is very complex and is controlled by different proteins called 'cytokines', which are released by the pathogens and the host in response to an inflammation. The process leads, directly or indirectly, to destruction of the periodontal structures. Among these substances are the immunoglobulins, interleukins,

\footnotetext{
${ }^{\star}$ Corresponding author

e-mail: czupkallo@gmail.com
}

prostaglandins, metalloproteinases, lipopolysaccharides and many more. A healthy body maintains a balance between the etiologic factors for periodontitis and the host's defence mechanisms. However, there are many factors favouring the intensification and affecting the course of inflammation: poor oral hygiene, dental calculus, caries, incorrect fillings or prosthetic appliances and re-implanted teeth. Such common and well-tolerated local factors are capable of revealing harmful effects if a factor of general nature emerges, such as pregnancy, blood disease or endocrinopathy.

An imbalance between dental plaque and the body's defence can be a triggering factor for the development of gingivitis.

Periodontal disease is characterized by a non-homogenous course with concomitant remissions and exacerbations. In the exacerbation phase, the tissues surrounding the teeth, including the bone tissue, are being actively damaged. This process, if not curbed at the right time, leads to loosening and subsequent loss of teeth. 


\section{OSTEOGENIC CELLS (OSTEOBLASTS)}

Osteoblasts arise from multipotent mesenchymal stem cells, and are responsible for the secretion of the organic components of the bone matrix, or collagen (type I) and proteoglycans, as well as for the synthesis of osteocalcin, osteopontin and proteinases. Their functions are also regulated by parathormone (PTH) and 1,25-dihydroxyvitamin D $\left(1,25(\mathrm{OH})_{2} \mathrm{D}_{3}\right)$ [23]. The differentiation of osteoclasts is due to modification of osteoblasts through expression of RANKL that activates the development of osteoclasts, and to secretion of osteoprotegerin (OPG) that blocks the effect of RANKL [23]. The proliferation and maturation of osteoblasts is influenced by many other growth factors (IGF1, IGF2, TGF- $\beta 1$, TGF- $\beta 2$, BMP, FGF, VEGF and PDGF). Pro-inflammatory cytokines, such as IL-1 or TNF, play a role in the induction of osteogenic cells and increase RANKL expression, thus causing disorders of bone metabolism.

\section{OSTEOCLASTS}

Osteoclasts are 50 to $100 \mu \mathrm{m}$ in diameter, and have prominent Golgi apparatus and eosinophilic cytoplasm that is rich in mitochondria, lysosomes and polyribosomes. Osteoclasts also have polarity. This is due to plications within the cell membrane in the form of microvilli located on the side of the bone tissue surface (a so-called ruffled border). The ruffled border plays an important part in bone resorption that is taking place in Howship's lacunae. Contact between osteoclasts and bone matrix is possible due to integrins $\alpha v \beta 3$ present on their surface. Their occurrence and activity can be inhibited by the following factors: oestrogens, OPG, IL-4, IL-18, TGF- $\beta$, IFN- $\gamma$, FGF-2, calcitonin and bisphosphonates $[21,23]$. On the contrary, IL-1, IL-6, IL-11, TNF, PGE, M-CSF and vitamin D3 induce osteoclast formation through RANKL production stimulated by osteoblasts and bone marrow stromal cells [23,27]. As a consequence of bone degradation, the local growth factors, i.e. TGF- $\beta$, FGF or BMP are released from the matrix to stimulate the maturation of the precursors of osteoblasts that produce osteoprotegerin (OPG), the main osteoclastogenesis inhibitor $[17,18,23]$.

\section{OSTEOCLASTOGENESIS}

The regulation of osteoclastogenesis, and, consequently, of bone resorption, is influenced by the following factors:

- generally acting hormones,

- locally acting hormones,

- the effects of cell-cell interactions (osteoblast/bone marrow stromal cell-precursor/osteoclast) [1].

It has been found that it is osteoblasts and bone marrow stromal cells, not osteoclasts, that have receptors for the hormones responsible for the stimulation of bone resorption. These are: 1,25 $(\mathrm{OH})_{2} \mathrm{D}_{3}$ and PTH.

Under the action of these hormones, such cells produce and release into the environment a number of factors acting in a paracrine or autocrine manner. Among these are the Macrophage Colony - Stimulating Factor (M-CSF), interleukins (IL-1, IL-6, IL-11) or prostaglandin $\mathrm{E}_{2}\left(\mathrm{PGE}_{2}\right)$.
The effects of cell-cell interactions (osteoblast/bone marrow stromal cell-precursor/osteoclast), in which relevant receptors and ligands are bound to cell membranes, are of great importance for the osteoclastogenesis and the activation of mature multinucleated osteoclasts. This system consists of three elements: a RANK receptor, osteoprotegerin and a ligand for the RANK receptor (RANKL) [1].

\section{RANKL/RANK/OPG PATHWAY}

Proper osteoclast maturation and function are dependent on a pathway comprising osteoprotegerin (OPG), the Receptor Activator of Nuclear Factor $-\kappa$ B (RANK) and its RANK ligand (RANKL - Receptor Activator of Nuclear Factor $-\kappa$ B ligand) $[4,10,25]$. A fully active osteoclast is formed due to the activation of a cascade mechanism inside a maturing bone resorption cell, resulting from the binding of the Receptor Activator for Nuclear Factor $\kappa \mathrm{B}$ ligand (RANKL) with the Receptor Activator of Nuclear Factor $\kappa$ $\mathrm{B}$ (RANK) on the surface of osteoclast precursor cells. This process involves osteoprotegerin (OPG), which is a protein from the tumour necrosis factor receptor family $[8,24]$. The expression levels of RANKL (increase of resorption) and OPG (increase of bone formation) proteins can be influenced by a number of substances and cytokines (Table 1) [25].

Table 1. The impact of different factors on the level of expression of OPG and RANKL (table description: 0 - no change; $\downarrow$ - inhibit; $\uparrow$ - stimulate; ? - no scientific reports) $[1,19]$

\begin{tabular}{|l|c|c|}
\hline \multicolumn{1}{|c|}{ Cytokine } & Increase of resorption & $\begin{array}{c}\text { Increase of bone } \\
\text { formation }\end{array}$ \\
\hline BMP2-7 & 0 & $\uparrow \downarrow$ \\
\hline TGF- $\beta$ & $\downarrow$ & $\uparrow$ \\
\hline IGF-1, IGF-2 & 0 & $\uparrow \downarrow$ \\
\hline FGF & 0 & $?$ \\
\hline PTH & $?$ & $\uparrow$ \\
\hline PDGF & $\uparrow$ & $\uparrow$ \\
\hline TNFa & $\uparrow$ & $\uparrow \downarrow$ \\
\hline IL-1 & $\uparrow$ & $?$ \\
\hline IL-3 & $\uparrow$ & $?$ \\
\hline IL-6 & $\uparrow$ & $\uparrow \downarrow$ \\
\hline PGE 2 & $\uparrow$ & $\uparrow$ \\
\hline INFY & $\uparrow$ & $\uparrow$ \\
\hline 17 -estradiol & $\uparrow$ & $\uparrow$ \\
\hline 1,25 (OH)2 vit.D3 & $\uparrow$ & $\downarrow$ \\
\hline Calcium & $\uparrow$ & $\uparrow$ \\
\hline Glucocorticoids & $\uparrow$ & $\uparrow$ \\
\hline Immunosupressants & $\uparrow$ & $\uparrow$ \\
\hline
\end{tabular}

\section{OSTEOPROTEGERIN}

Osteoprotegerin (OPG) is a protein that was first described in 1997. It was identified as a secreted molecule that inhibits the differentiation and activity of osteoclasts, i.e. as an osteoclastogenesis inhibitory factor $[1,4,25]$. OPG is a member of the tumour necrosis factor receptor (TNFR) superfamily and is synthesized predominantly by osteoblasts and many organs (lungs, liver, intestines, kidneys, stomach, 
skin, bones), as well as by periodontal tissues, gingival epithelium and gingival fibroblasts [5,23]. Like RANKL, OPG is modulated by the inflammatory cytokines present in periodontitis [2].

Osteoprotegerin is a dummy receptor that competitively binds to RANKL/OPGL [28]. This prevents osteoblasts and bone marrow stromal cells from contacting both the precursors and the mature multinucleated osteoclasts having a RANK receptor, and results in inhibition of osteoclastogenesis (Figure 1).

A

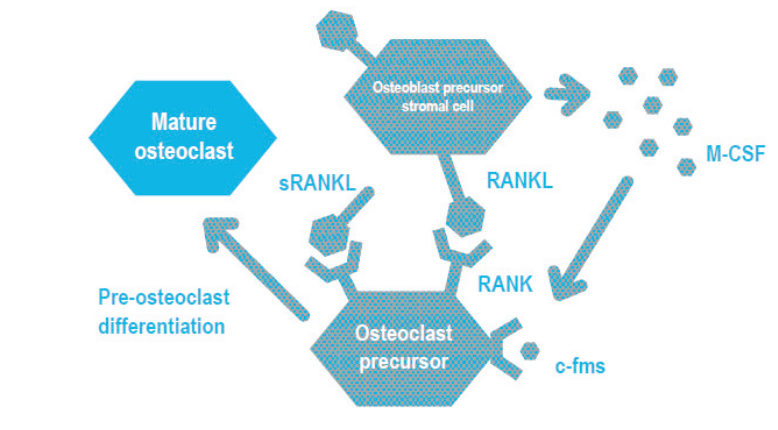

B

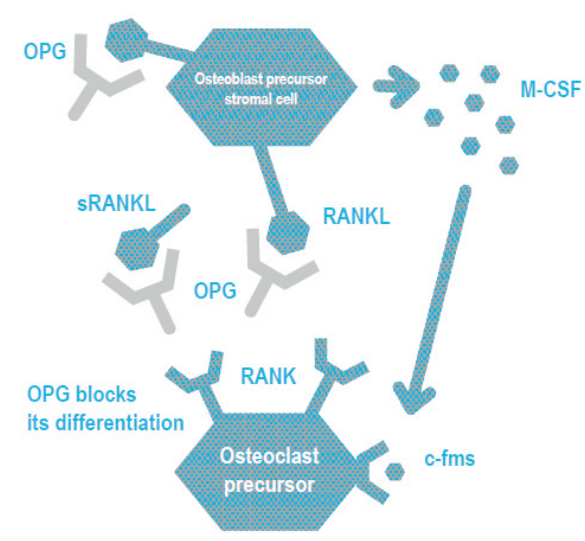

Figure 1. Participation of proteins of the RANK/RANKL/OPG system and other osteolytic factors in the regulation of osteoclastogenesis. A-activation of differentiation of the osteoclast precursor by RANKL and M-CSF; B-inhibition of the differentiation and maturation of osteoclasts by osteoprotegerin $[1,2]$

OPG expression is promoted by many factors, such as interleukins (IL-1 $\alpha$, IL-6, IL-11, IL-13, IL-18), growth factors (PDGF, TGF- $\beta 1$ ), $17 \beta$-estradiol, OSM (oncostatin M) or mechanical loads exerted on bone [19]. In contrast, OPG inhibitors are: parathormone (PTH), $\mathrm{PGE}_{2}$, immunosuppressive drugs, glucocorticoids, vitamin $\mathrm{D}_{3}$ and its derivatives $[1,2,4,19,20,22]$.

\section{RANK LIGAND (RANKL)}

RANKL (Receptor Activator for Nuclear Factor $\kappa$ $B$ Ligand) belongs to the protein superfamily of tumour necrosis factors (TNF) and is a product of mature osteoblasts, along with their precursors, fibroblasts, chondrocytes, endothelium, bone marrow stromal cells, malignant cells or active T lymphocytes. It is a factor that activates formation of mature osteoclasts: their differentiation, fusion, function and survival. RANKL acts via the RANK receptor (Receptor Activator for Nuclear Factor $\kappa \mathrm{B}$ ) present on the cell surfaces [1]. RANKL activates osteoclastogenesis by blocking apoptosis of osteoclasts, while binding to RANK which is present on the surface of resorption cells, or osteoclasts [6,23] (Figure 2).

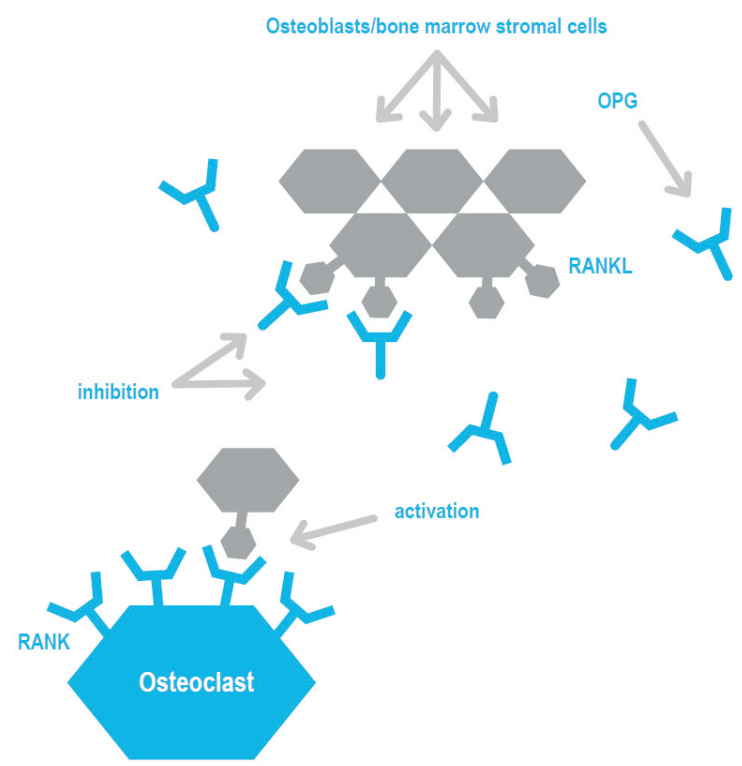

Figure 2. RANKL/RANK/OPG interaction. RANKL-RANK binding on pre-osteoclasts is essential for their maturation and subsequent activity. With the help of M-CSF, RANKL activates osteoclastogenesis by blocking apoptosis of osteoclasts while binding to the RANK present on the surface of resorption cells, or osteoclasts $[1,2]$

RANKL gene expression is blocked by $17 \beta$-estradiol, and by IL-13 or TGF- $\beta 1$ as well $[19,23]$. Moreover, $1,25(\mathrm{OH})_{2} \mathrm{D}_{3}$, IL-1 $\beta$, IL-6, IL-7, IL-11, IL-17, TNF, PTH, OSM, IFN- $\gamma, \mathrm{PGE}_{2}$ vitamin $\mathrm{D}_{3}$, glycocorticosteroids and dexamethasone promote an increase in gene expression for RANKL in the presence of M-CSF $[1,19,23,25]$.

\section{RECEPTOR ACTIVATOR OF NUCLEAR FACTOR - K B (RANK)}

RANK is a type I glycoprotein from the TNF receptor superfamily that is the receptor RANKL, or the most important cytokine that is responsible for the development and maturation of osteoclasts. It is a transmembrane protein that can be found in mature osteoclasts and their precursors, fibroblasts, T and B lymphocytes, chondrocytes, endothelial cells, dendritic cells, and in malignant cells as well $[1,2,11,13,19,23,28]$. Increased RANK expression is due to the activity of RANKL, IL-1, MIP-1 $\alpha$, VIP, oncostatin M (OSM), vitamin $\mathrm{D}_{3}$, TGF- $\beta$ and IFN- $\gamma$, whereas the reduction of the number of RANK molecules on the surface of osteoclasts may be induced by IL-4 $[1,2,4,23,26]$.

\section{RANKL AND OPG EXPRESSION IN PERIODONTAL DISEASE}

Numerous studies showed that IL-1, IL-6 and TNF- $\alpha$, as well as other inflammatory cytokines, are significant in 
periodontal disease due to the fact that they control RANKL and OPG expression $[3,25]$. OPG and RANKL are regarded as the main bone metabolism regulators and are also considered to be crucial for the mechanism of periodontal destruction in periodontitis [3].

Inflammatory cell infiltration in chronic periodontal disease leads to bone atrophy in periodontitis. This situation is reflected in increased RANKL and decreased OPG in the inflammatory granulation tissue adjacent to the atrophied bone. [3.25]. According to Nagasawa et al., RANKL expression is higher in deeper periodontal pockets, compared to the physiological gingival pockets $[15,16]$. Liu et al. also confirmed that the RANKL level was higher in people with the advanced stage of periodontal disease, compared to those with moderate periodontitis or those who are healthy $[4,12,15]$.

RANKL mRNA expression was observed in inflammatory cells, mainly in lymphocytes and macrophages. Furthermore, the proliferating epithelium in the region of proinflammatory cells also exhibited increased expression of RANKL mRNA [2,15].

Using immunohistochemical methods, Crotti et al. compared RANKL and OPG expression in the inflammatory granulation tissue adjacent to the places of bone atrophy in periodontal patients with the parodontal tissues, and in patients without any symptoms of periodontal disease $[2,15]$. Herein, the level of RANKL proteins was significantly higher in tissues with clinical parodontopathy, whereas the OPG level turned out to be clearly lowered $[2,15,25]$.

Mogi et al. measured RANKL and osteoprotegerin concentrations in Gingival Crevicular Fluid (GCF) in patients with periodontitis and in healthy ones. Increased RANKL and decreased OPG were obtained for the group with diagnosed periodontitis. Furthermore, the ratio of the concentration of RANKL to that of OPG in Gingival Crevicular Fluid was significantly higher in that group, compared to the ratio found for the group of healthy people $[14,15]$.

The RANKL/OPG ratio can be seen as the main determinant of bone metabolism. In many situations, bone absorption is stimulated by both the increased RANKL level and the decreased OPG level which act as pro-resorptive signals [9].

The mechanisms behind the bone resorption process in periodontal disease is still being investigated. Progress in medicine is extremely fast, and medical discoveries made ten years ago often become anachronisms. Still, a willingness is triggered amongst researchers to discover what has not been fully investigated yet. Amongst such targets are (for example) the regulation effect and mechanisms in other physiological and pathological situations of the organism.

Currently, sRANKL and OPG as inflammatory process markers, seem to have as yet limited practical applications due to the multitude of tissues that are sources of the proteins in question. However, the role of RANKL inhibitors as therapeutic agents for treatment of conditions involving bone mass loss, as for example postmenopausal osteoporosis, myeloma or breast carcinoma, is promising $[9,10]$.

\section{DECLARATION OF INTEREST STATEMENT}

No competing financial interests exist amongst the researchers contributing to this article.

\section{ABBREVIATIONS THAT WERE USED IN THE TEXT:}

BMP - Bone Morphogenetic Protein; GCF - Gingival Crevicular Fluid; FGF - Fibroblast Growth Factor; IFN- $\gamma$ - Interferon gamma; IL - Interleukin; IGF - Insulin-Like Growth Factor; M-CSF Macrophage Colony-Stimulating Factor; NF- $\kappa \mathrm{B}$ - Nuclear Factor kappa B, Nuclear Factor kappa-light-chain-enhancer of activated B cells ; OPG - Osteoprotegerin; OPGL - Osteoprotegerin Ligand; OSM - Oncostatin M; PDGF - Platelet-Derived Growth Factor; $\mathrm{PGE}_{2}$ - Prostaglandin $\mathrm{E}_{2}$; PTH - Parathyroid hormone; RANK Receptor Activator of Nuclear Factor $-\kappa$ B; RANKL - Receptor Activator of Nuclear Factor $-\kappa$ B ligand; sRANKL - soluble RANKL; TGF- $\beta$ - Transforming growth factor $\beta$; TNF - Tumor Necrosis Factor; TNFR - Tumor Necrosis Factor Receptor; VEGF - Vascular Endothelial Growth Factor

\section{REFERENCES}

1. Badurski E. (2005). Choroby metaboliczne kości. Borgis. Warszawa.

2. Boyce B.R., Xing L.: Biology of RANK, RANKL and osteoprotegerin. Arthritis Research \& Therapy, 9, 1, 2007. online: http://arthritisresearch.com/content/9/S1/S1.

3. Crotti T. et al.: Receptor activator NF kappaB ligand (RANKL) and osteoprotegerin (OPG) protein expression in periodontitis. J. Periodontal Res., 38, 380-387, 2003.

4. Darmochwał-Kolarz D. et al.: The concentrations of markers of bone turnover in normal pregnancy and preeclampsia. Hypertens. Pregn., 31, 166-176, 2012

5. Heath D.J. et al.: An osteoprotegerin-like peptidomimetic inhibits osteoclastic bone resorption and osteolytic bone disease in myeloma. Cancer Res., 67, 202-208, 2007.

6. Holen I., Shipman C.M.: Role of osteoprotegerin (OPG) in cancer. Clin. Sci., 110, 279-291, 2006.

7. Jankowska A. (2009). Stężenie osteoprotegeryny i liganda receptora aktywujacego czynnik jądrowy kappa $b$ w przebiegu nieswoistych zapaleń jelit u dzieci. Praca na stopień doktora nauk medycznych. Gdańsk.

8. Kiryłów E., Kamieński G.: Miejsce biochemicznych markerów obrotu kostnego w zaleceniach diagnostyczno-leczniczych osteoporozy. Pol. Merk. Lek., 25, 48, 2008.

9. Kostenuik P.J.: Osteoprotegerin and RANKL regulate bone resorption, density, geometry and strength. Current Opin Pharmacol., 5, 618-625, 2005.

10. Kryśkiewicz E., Lorenc R.S.: Szlak RANKL/RANK/OPG i jego znaczenie w fizjologii i patofizjologii kości. Terapia (on-line), 3, 177, 2006.

11. Lerner U.H.: New molecules in the tumor necrosis factor ligand and receptor superfamilies with importance for physiological and pathological bone resorption. Crit. Rev. Oral Biol. Med., 15, 64-81, 2004.

12. Liu D. et al.: Expression of RANKL and OPG mRNA in periodontal disease: possible involvement in bone destruction. Int. J. Mol. Med., $11,17-21,2003$

13. Manolagas S.C.: Birth and death of bone cells: basic regulatory mechanisms and implications for the pathogenesis and treatment of osteoporosis. Endocr. Rev., 21, 115-137, 2000.

14. Mogi M. et al.: Differential expression of RANKL and osteoprotegerin in gingival crevicular fluid of patients with periodontitis. J. Dent. Res., 83,166-169, 2004. 
15. Nagasawa T. et al.: Roles of receptor activator of nuclear factorkappaB ligand (RANKL) and osteoprotegerin in periodontal health and disease. Periodontol. 2000, 43, 65-84, 2007.

16. Nagasawa T.A et al.: LPS-stimulated human gingival fibroblasts inhibit the differentiation of monocytes into osteoclasts through the production of osteoprotegerin. Clin. Exp. Immunol., 130, 338-344, 2002.

17. Rahnama M., Świątkowski W., Zaręba S.: An assessment of the alkaline and acid phosphatase activity in rats serum during experimental postmenopausal osteoporosis. Rocz. Państ. Zakł. Hig., 53, 3, 283-291, 2002.

18. Rahnama M.: New aspects of osteoporosis - a literature review. Ann. UMCS Sect. D., 57, 2, 365-368, 2002.

19. Rahnama M. (2009): Osteoporoza pomenopauzalna $w$ badaniach doświadczalnych i klinicznych. Ocena wpływu poziomu wybranych markerów obrotu kostnego, ekspresji ich genów oraz szlaku RANKL/ RANK/OPG na gęstość tkanki kostnej. Medical University of Lublin.

20. Rogers A., Estell R.: Circulating osteoprotegerin and receptor activator for nuclear factor B ligand: clinical utility in metabolic bone disease assessment. J. Clin. Endocrinol. Metab. 90, 6323-6331, 2005.

21. Roodman G.D.: Regulation of osteoclast differentiation. Ann. N.Y. Acad. Sci., 1068, 100-109, 2006.
22. Schoppet M., Preissner K.T., Hofbauer L.C.: RANK ligand and osteoprotegerin: paracrine regulators of bone metabolism and vascular function. Arterioscler. Thromb. Vasc. Biol., 22, 549-533, 2002.

23. Stanisławowski M., Kmieć Z.: Udział RANK, RANKL i OPG w osteolizie towarzyszącej nowotworom. Post. Hig. Med. Dosw. (online)., 63, 234-241, 2009.

24. Torring O. (2005). Metabolizm tkanki kostnej. W: Hiperkalcemia w przebiegu nowotworów złośliwych i innych stanach chorobowych. Accurant Information AB. Uppsala, Elanders Tofters.

25. Vernal R. et al.: High expression levels of receptor activator of nuclear factor-kappa B ligand associated with human chronic periodontitis are mainly secreted by CD4+ T lymphocytes. J. Periodontol., 77, 10, $1772-1780,2006$

26. Vitoratos N. et al.: Maternal circulating osteoprotegerin and soluble RANKL in pre-eclamptic women. Eur. J. Obstet. Gynecol. Reprod. Biol., 154, 2, 141-145, 2011.

27. Wittrant Y. et al.: RANKL/RANK/OPG: new therapeutic targets in bone tumours and associated osteolysis. Biochim. Biophys. Acta, 1704, 49-57, 2004.

28. Yuan H. et al.: Receptor activator of nuclear factor kappa B ligand antagonists inhibit tissue inflammation and bone loss in experimental periodontitis. J. Clin. Periodontol., 38, 11, 1029, 2011. 